\begin{tabular}{c} 
Volume and Issues Obtainable at Center for Sustainability Research and Consultancy \\
Journal of Accounting and Finance in Emerging Economies \\
ISSN: 2519-0318 ISSN (E) 2518-8488 \\
Volume 7: Issue 1 March 2021 \\
CSRᄃ \\
Journal homepage: www.publishing.globalcsrc.org/jafee \\
\hline
\end{tabular}

\title{
Role of Value Added and Conventional Accounting Measures in Stimulating Stock Market Returns: A Study of Non-Financial Sector Listed at Pakistan Stock Exchange
}

\footnotetext{
${ }^{1}$ Nosheen Rasool, ${ }^{2}$ Safi Ullah, ${ }^{3}$ Muhammad Mubashir Hussain, ${ }^{4}$ Muhammad Usman

${ }^{1}$ In-charge, Department of Commerce \& Finance, GC University, Lahore, Pakistan, nosheen.rasool@gcu.edu.pk

${ }^{2}$ Credit officer SME/COMM, Meezan Bank Ltd, Lahore, Pakistan, Safimirza47@ hotmail.com

${ }^{3}$ Assistant Professor, Management Studies Department, GC University Lahore, Pakistan, mhdm.hussain@gcu.edu.pk

${ }^{4}$ Assistant Professor, Hailey College of Commerce, University of the Punjab,Lahore,Pakistan, usman@hcc.edu.pk

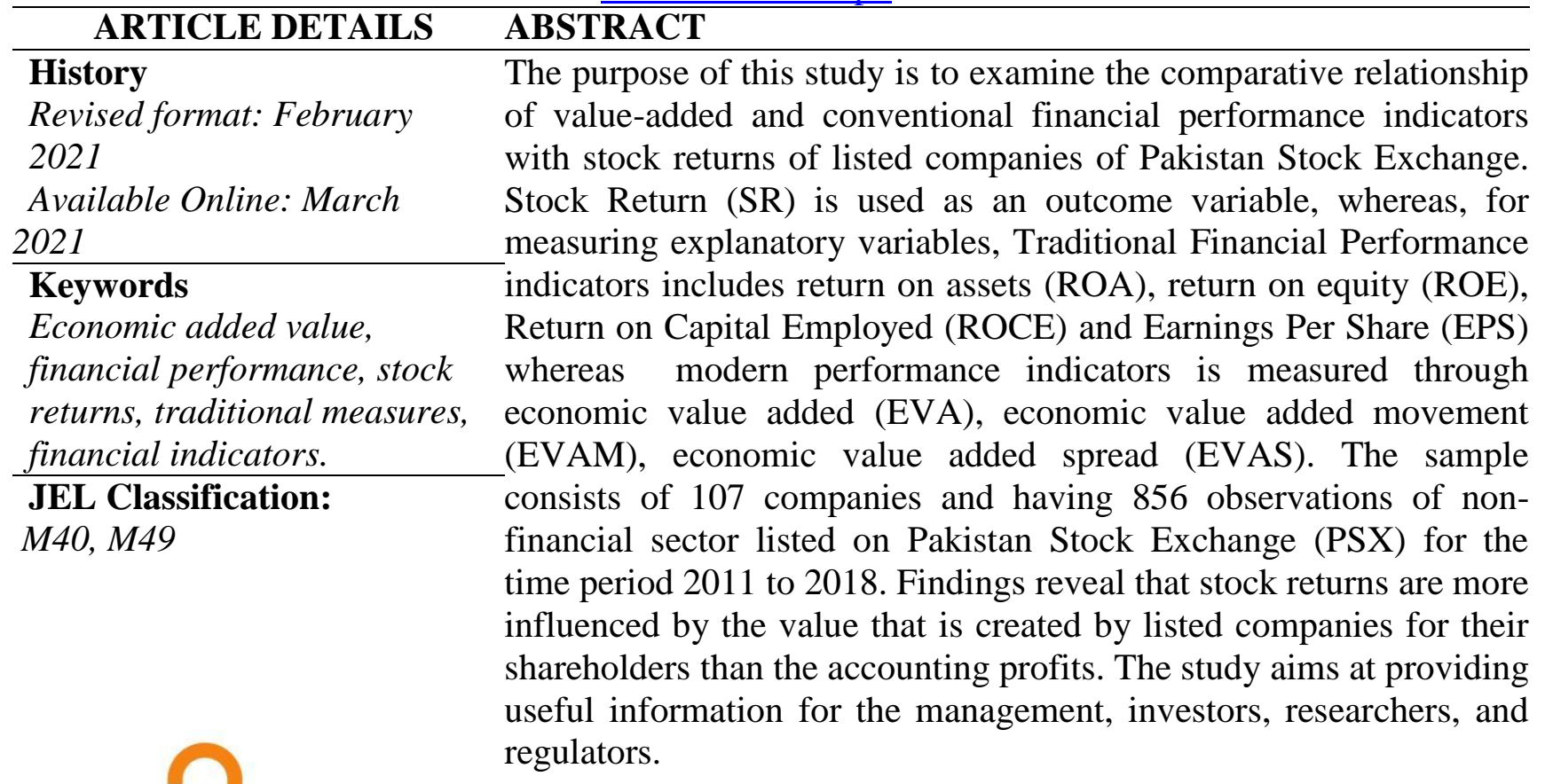

(C) 2021 The authors, under a Creative Commons AttributionNonCommercial 4.0

Corresponding author's email address: nosheen.rasool@gcu.edu.pk

Recommended citation: Rasool, N., Ullah, S., Hussain, M. M. \& Usman, M. (2021). Role of Value Added and Conventional Accounting Measures in Stimulating Stock Market Returns: A Study of Non-Financial Sector Listed at Pakistan Stock Exchange. Journal of Accounting and Finance in Emerging Economies, 7(1), 217-232

\section{Introduction}

In the past few decades, the activist shareholders created immense pressure on firms to increase shareholder's wealth at maximum level (Smith, 1996). However, the firms with high market capitalization failed to provide substantial value to their shareholders. The main reason was the unidentified key performance measure that would reflect the actual profitability of firms. To determine the financial success of firms, traditional accounting measures had always been in 
substantial use until the late '90s. These measures were left behind due to some crucial reasons; it ignored the cost of obtaining the capital, and with the change in accounting policy, it can

easily be manipulated. These failures diverted the attention of many researchers towards key performance indicators that would measure the actual performance of the company in comparison to its cost and also to improve the shareholder's wealth.

In today's world, keeping in view the value-based performance measures, it has become a common goal of every organization i.e. to maximize shareholders wealth. To monitor the shareholder's wealth, financial managers are supposed to evaluate the financial performance of organization that is among the vital steps in the firm evaluation process and the results of financial performance analysis indicate a direction for managers to make decision regarding financial structure, investment, and management issues. Mostly, the performance of publicly listed companies is predicted through their share prices. But due to some financial as well as political uncertainty, share price is limited to reflect financial performance of a company as a whole and does not reflect at individual projects level (Wirawan, 2011).

In the financial environment, the corporate sector faces various challenges in analyzing the performance of companies in terms of financial management. To deal with these challenges, several Financial indicators including return on assets (ROA), return on equity (ROE), earning per share (EPS), return on invested capital (ROIC), and return on investment (ROI), emerged as financial indicators, are used to evaluate the financial health of a company. However, these indicators failed to provide the real maximized value to shareholders (S. A. Panigrahi, 2017).

In addition to EVA, economic value-added momentum (EVAM) is also used to monitor the change in economic profit with respect to trailing sales. It provides the on-going performance of economic profit which is used by investors. EVA Spread is another metric use to determine the excess value of economic profit from invested capital. İt is also considered as superior performance measure as compared to the accounting measures because it reflects true value of profit earned from the capital invested in the company (Maeenuddina et al., 2020a).

Despite the myriad advantages, EVA has also faced some limitations and criticisms due to its absolute numeric measure. This metric does not take into account the size differences of companies. So, it could be difficult for investors to compare firms of different sizes by using EVA as a sizeneutral metric. Moreover, this metric shows inconsistency in the calculation of invested capital in which WACC is based on the market value of debt and equity and used to adjust the book value of the firm's debt and equity. In most companies, compensation of managers is based on the performance goals, but it is difficult to trace their compensation from the incremental performance by using this performance metric(Johan, 2018).

İn developing countries, like Pakistan, where stock markets are intensely tentative, it is nearly impossible to use financial performance metrics like EPS, P/E ratio and ROE, especially when markets are highly reactive to political uncertainties and unanticipated shocks. Furthermore, they are also highly manipulated by giant investing bodies for their self-interest. In these circumstances, investors would be in dire need of metrics like EVA that maximizes shareholding value. These value-added metrics are highly useful in markets like PSX because they provide not only the realtime figure of economic profits that can be obtained by investing in a particular company but also maximizes the shareholder's wealth by influencing the stock return. Keeping in view, this study aims to provide the empirical evidence of determining the influence of economic value-added metrics and traditional accounting metrics on the shareholder's wealth in PSX.

This study emphasis on corporate/non-financial sector of Pakistan. The non-financial sector plays a pivotal role in economic growth and sustainability. Corporate sector contributes $13.6 \%$ to GDP of Pakistan as per Economic Survey 2017-18. Financial Statement Analysis of Non-Financial sector (State Bank of Pakistan) indicated 19.23\% growth in sales during the financial year 2018 as compared to the previous financial year 2017. Moreover, in line with the previous studies, Financial 
sector is excluded from the sample due to the difference of legal regulatory and financial framework (Ciftci et al., 2019).

\section{Literature Review}

The wide review of previous studies shows that some well-recognized researchers got acquainted with the value-added metrics to measure the economic profits and the value provided

to the shareholders in addition to the cost of capital. Initially, G. B. Stewart (1990) recognized through his research that the EVA metric as the value-added performance measure reflects the actual value maximization for the shareholders. The concept of EVA Momentum was also developed by Bennett Stewart (2009) as a new financial measurement tool. Considering the theoretical flaws of using accountings measures (earning per share, sales growth rate, return on capital, profit margin), he concluded that EVA momentum is best financial performance indicator. EVA can be determined by deducting the earnings before interest and after-tax, or NOPAT, from the capital charge. It means EVA will recognize the profit only after covering its cost of capital. Peixoto (2002) conducted the research that extended the Stewart hypothesis by using operating profit (OP), economic value added (EVA), and net profit (NP) along with the market value (MV) of Portuguese public companies.

Contrary to G. B. Stewart, Gary C Biddle et al. (1997) argued that EVA does not have any superior association with stock returns as compared with accrual earnings. He further suggested that earnings better evaluate the fluctuation in stock returns and firm values. In line with the previous studies, G. C. Biddle et al. (1998) further explored the other aspects of EVA and focused EVA as the internal performance indicator of a firm. They conducted the study to test the Stewart's assertion of EVA as internal management performance tool and concluded arguments in the favor of Stewart that the adoption of EVA as internal measurement tool and linking management incentive with EVA would outperform the traditional accounting tools.

Many researchers have measured the financial performance of firm by using traditional measures only. Har and Ghafar (2015) examined the impact of ROE, ROCE and ROA on stock returns. All measures have shown the positive and significant impact on stock returns. Menike and Prabath (2014) Investigated the impact of book value, earning per share and dividend per share on stock return and shown the positive and significant impact of these variables with stock returns. Khadafi et al. (2014) listed that ROE, ROE, NPM DER and CR are important for assessing the profit growth of corporation.

Economic value added was used by various researchers in their studies to measure stock return of firms. Economic Value Added (EVA) is a superior operating performance, and it reflects a stock's intrinsic value (Awan et al., 2014). Patel and Patel (2012) also analyzed the impact of economic value added on share price in India where they found a positive correlation between EVA and share price only in one bank namely Kotak Mahindra Bank. Mengi and Bhatia (2017). Panigrahi et al. (2014) also measured stock return with EVA and shown it a significant measure. EVA together with other measures have more power in explaining the stock returns (Maditinos et al., 2009).

In many studies, modern performance measures have been considered to have impact on stock returns than conventional measures (Parab \& Reddy, 2018). Worthington and West (2004) investigated whether the conventional accounting measures or EVA is more associated with the stock returns and concluded that EVA has a stronger impact on stock returns than residual income, earnings and net cash flow. These results were also consistent with the O'Byrne (1996); Mengi and Bhatia (2017). Gounder and Venkateshwarlu (2017) researched to investigate the relationship of conventional and modern bank performance measures with MVA and importance of EVA. Findings have shown EVA as a significant measure of MVA but it is not used efficiently by firm to measure stock return and they have suggested to use it. S. K. Panigrahi (2017) analyzed the effect of conventional and value-added measures on shareholder value in Malaysia. In Indonesia, Amyulianthy and Ritonga (2016) tried to examine how Economic value added and Earnings per 
share affect stock return. These results were in consistent with Lehn and Makhija (1997). (AlAwawdeh, 2018) researched on stock market returns and finds out that EVA and ROA are should be used to measure the stock return. EVA is a significant measure of stock return as EVA increase shareholder's wealth also increased but this measure is usually ignored by companies for measuring stock return (Panigrahi et al., 2014).

However, De Wet (2005) conducted a comparative analysis of EVA and conventional performance measures in relation with the shareholder value and concluded no superiority of EVA. The study conducted by Visaltanachoti et al. (2008), explained the impact of Economic value-added information content on returns. The study concluded that conventional accounting

measures outperformed EVA in explaining the influence of information content on sector returns. Moreover, its findings also showed that operating cash flows and accruals outperformed the crucial component of EVA i.e. capital charge in providing valuable information content. Later on, Shubita (2013) analyzed the information content of EVA and accounting measures in Jordan and concluded that information content of EVA does not outperform net income and residual income. Nakhaei and Hamid (2013) also explored a research in which they analyses the relationship between EVA, accounting variables and share market value and concluded EVA has significant relationship with share market value but other accounting variables were more important for share performance then EVA. This study finding matched to Worthington and West (2004). Fayed and Dubey (2016a) also conducted an empirical study on the impact of EVA momentum on the shareholders' value creation as compared to traditional financial performance measures and found that traditional performance provides significant and relevant information on MVA than EVA.

Following studies were conducted in Pakistan on traditional accounting measures and EVA. Aslam and Khan (2015) analyzed the performance of companies by encountering EVA and traditional measures as predictors of firm performance. They conducted a research in Pakistan to analyze the impact of accounting information on stock prices. For this purpose, the study selected EPS and BVPS as predictors of share price. Furthermore, Muhammad and Scrimgeour (2014) analyzed the impact of accounting based financial measures and market-based financial measures on stock returns. In Pakistan's context, Khan et al. (2012) used OCF, ROA, ROE and EVA as performance metrics. The impact of EPS, BVPS on share price have been evaluated by Shehzad and Ismail (2014). Ismail et al. (2014) explored the accounting measures and value added measures in association with stock return. Hunjra et al. (2014) focused on impact of EPS, PAT, DPR, DY and ROE on stock prices in Pakistan. Saleh (2015) also analyzed the impact of accounting variables on stock returns in Pakistan.

Maitah et al. (2015) tried to investigate the relationship between EVA and the total return in Egypt. Accordingly, the study explored the relationship between EVA and share price. Baybordi et al. (2015) evaluated the impact of EVA on stock returns for companies listed at Tehran Stock Exchange. Anwaar (2016) examined the effect of accounting variables on stock returns. QR, EPS, ROA, ROE and NMP were independent variables. In Malaysia, Mahmood et al. (2008) focused on the property sector to evaluate the effect of adoption of EVA metric. Sekyere (2016) tried to investigate the impact of EVA in addition to traditional variables on stock returns during the great recession period (2007-2009) in USA. In a research, Sauro and Tafirei (2016) tried to explore the association between economic value added and stock return.

By the review of above studies, it became clear that both traditional accounting measures and valueadded measures are highly in use while assessing the firm's performance. However, due to some considerable flaws detected in accounting measures, the economic value-added measures reflect more accurate and pure economic profits. But, there are very few studies in Pakistan which have evaluated a better measure for stock return among traditional accounting measures or EVA. Therefore, in order to determine the impact of traditional accounting measures and economic valueadded measures on the stock returns of listed companies, this paper contributes some empirical 
evidence towards analyzing the relationship individually and jointly. So, this paper identifies some value-added measures such as EVA, EVAMA, EVAM and EVAS, and accounting measures ROCE, ROE, EPS and ROA.

\section{Methodology}

\subsection{Sample of the study}

For the purpose of this research, secondary panel data is obtained from financial statements of 107 Public limited companies of corporate sector, which are listed at Pakistan Stock Exchange (PSX). While obtaining the sample, it is ensured that data of each company over the period of 2011 to 2018 is entirely available, stock returns of each company were obtained from historical data of PSX and Financial sector is excluded from the sample due to the difference of legal regulatory and financial framework (Ciftci et al., 2019).

\subsubsection{Explanatory Variables}

In this research, Economic Value Added (EVA), Economic Value-Added Momentum (EVAM), Economic Value-Added Margin (EVAMA), and Economic Value-Added Spread (EVAS) are taken as value added accounting measures. Economic value added is the value-added financial performance indicator that depicts the wealth created by shareholders encountering the cost of equity capital in addition to cost encountered by conventional performance indicators. It is also known as economic profit. Positive value of EVA indicates that company creates value for shareholders while negative value of EVA indicates that company has failed to create value for shareholders. Calculation and source of theses explanatory variables are given in table 2.

\subsubsection{Outcome Variable}

On the other hand, Stock return is taken as a outcome variable. It is the sum of capital gain and dividend announced by companies. Capital gain is the difference between ending share price and beginning share price divided by beginning price. Capital gain is the appreciation in share price. The closing share price at the 30th June of each year is considered for calculation of predicted variable. The dividend history of each company was obtained from financial statement of respective company.

\subsubsection{Empirical Strategy}

In the initial analysis, the panel data is processed through Levin-Lin-Chu Unit root test to check for the stationarity (Levin et al., 2002). Then afterwards, the Panel OLS regression technique is deployed initially in three models to check the dependency of stock returns on value added measures and conventional variables.

In model 1, the joint impact of economic value-added measures and conventional measures on stock return is analyzed.

$$
\begin{aligned}
& \mathrm{SR}_{\mathrm{it}}=\beta_{0}+\beta_{1} * E V A_{i t}+\beta_{2} * E V A M A_{i t}+\beta_{3} * E V A M_{i t}+\beta_{4} * E V A S_{i t}+\beta_{5} * R O C E_{i t}+\beta_{6} * R O E_{i t} \\
& +\beta_{7} * E P S_{i t}+\beta_{8} * R O A_{i t}+\mu_{i t}
\end{aligned}
$$

In model 2, impact of value-added measures is evaluated to check dependency of stock returns on these predictors.

$$
\mathrm{SR}_{\mathrm{it}}=\beta_{0}+\beta_{1} * \mathrm{EVA}_{\mathrm{it}}+\beta_{2} * \mathrm{EVAMA}_{\mathrm{it}}+\beta_{3} * \mathrm{EVAM}_{\mathrm{it}}+\boldsymbol{\beta}_{4} * \mathrm{EVAS}_{\mathrm{it}}+\mu_{i t}
$$

In model 3, impact of conventional measures is explored to analyze that whether these variables are significant in association with stock returns.

$$
\mathbf{S R}_{\mathrm{it}}=\boldsymbol{\beta}_{0}+\beta_{1} * \mathbf{R O C E}_{\mathrm{it}}+\boldsymbol{\beta}_{2} * \mathbf{R O E}_{\mathrm{it}}+\boldsymbol{\beta}_{3} * \mathbf{E P S}_{\mathrm{it}}+\boldsymbol{\beta}_{4} * \mathbf{R O A}_{\mathrm{it}}+\mu_{i t}
$$


In order to check these regression models for multicollinearity, autocorrelation and heteroskedasticity, Variance Inflating Factor is used for multicollinearity, Wooldridge test for serial correlation (Wooldridge, 2010), and Breusch-Pagan / Cook-Weisberg test for heteroskedasticity (Breusch \& Pagan, 1979). After the detection of serial correlation and heteroskedasticity, Feasible Generalized Least Square regression analysis is applied on all models for the correction of serial autocorrelation and heteroskedasticity.

\section{Data Analysis and Results}

The empirical analysis of panel data included Panel data summary, regression analysis of panel data, and various test to detect serial correlation, multicollinearity and heteroskedasticity among the panel data.

\subsection{Performance Indicators and Stock Returns}

In the initial stage, in order to determine the joint impact of economic value-added measures and traditional accounting measures on the stock returns, all explanatory variables were collectively regressed on stock return (Presented in Equation I)

$$
\mathrm{SR}_{\mathrm{it}}=\beta_{0}+\beta_{1} * E V A_{i t}+\beta_{2} * E V A M A_{i t}+\beta_{3} * E V A M_{i t}+\beta_{4} * E V A S_{i t}+\beta_{5} * R_{O C E}+\beta_{6} * R O E_{i t}+
$$

\section{$\beta_{7} * E_{P S}+\beta_{8} * R O A_{i t}+\mu_{i t}$}

The results of regression model, shown in Table 3, provided the highest R-square and indicated that the model significantly fits the data. The R-Square shows that more than $46 \%$ of variations in Stock Returns are due to Economic value-added measures and traditional accounting measures. The economic value-based measures studied being EVA, EVA momentum and EVA margin provide the statistically significant relationship with the Stock Return reporting the p-value of less than 1 percent while the traditional accounting measures mainly ROE, ROA, EPS and ROCE provided an insignificant relationship with stock return, which is inconsistent with the result of De Wet (2005). However, the coefficient of EVA margin was unexpectedly negative indicating the negative association with shareholders wealth creation. This unexpected result has shown the consistency with the unexpected insignificance of accounting measures. Classical assumptions of multiple regressions require that there should be no multicollinearity, autocorrelation and heteroskedasticity in model.

The assumptions of multicollinearity, heteroskedasticity, and autocorrelation are tested through the variance inflation factor, Breusch-Pagan / Cook-Weisberg test and Wooldridge test, respectively. The mean Variance inflation factor value shows that there is no multicollinearity as its value is less than 10. The Wooldridge test for autocorrelation in panel data shows that Prob. $>\mathrm{F}=0.000$ which indicates that null hypothesis of autocorrelation is rejected and autocorrelation is detected in model. Results of Breusch-Pagan / Cook-Weisberg test for heteroskedasticity shows that Prob. $>$ chi $2=$ 0.000. Therefore, it rejects the null hypothesis and heteroskedasticity is detected. To solve the problem of heteroskedasticity and autocorrelation, Feasible Generalized Least Square method is applied (Baum, 2001).

The results of FGLS regression, shown in Table 4, pointed out towards a joint insignificant between EVA, EVAMA, EVAM, EVAS ROA, ROE, EPS, ROCE and Stock Returns. As, ROE, EPS and ROCE reported the p-value of greater than 0.10. Hence, it is concluded that there is a joint insignificant impact of EVA, EVAMA, EVAM and EVAS being value-based measures and ROA being accounting measure on stock return of listed companies. It also shows that the economic value-added measures outperformed the conventional accounting measures in influencing the share's prices. 


\subsection{Value Added Measures and Stock Returns}

In second part of analysis, the impact of economic value-added measures on stock returns was analyzed by regressing EVA, EVAMA, EVAM and EVAS on SR.

$$
\mathbf{S R}_{\mathrm{it}}=\boldsymbol{\beta}_{\mathbf{0}}+\boldsymbol{\beta}_{\mathbf{1}} * \mathbf{E V A}_{\mathrm{it}}+\boldsymbol{\beta}_{\mathbf{2}} * \mathrm{EVAMA}_{\mathrm{it}}+\boldsymbol{\beta}_{\mathbf{3}} * \mathrm{EVAM}_{\mathrm{it}}+\boldsymbol{\beta}_{\mathbf{4}} * \mathbf{E V A S}_{\mathrm{it}}+\boldsymbol{\mu}_{i t}
$$

The results shown in Table 3, provided the R-Square of 0.4273 which means 42.73 percent of the variations in stock return are due to the economic value-added measures while the remaining are due to other factors. However, the F-statistic is significant at 1 percent which means the model significantly fits the data. The value-added performance indicators being the EVA, EVAMA and EVAM represents the significant relationship with the stock returns as reported the $p$-value of less than 1 percent level of significance while the coefficient of EVA spread among the performance indicators shows the insignificant relationship with the Stock Returns (Gupta \& Sikarwar, 2016).

Mean variance inflation factor value of this model shows that there is no multicollinearity as its value is less than 10. Wooldridge test for autocorrelation in panel data shows that Prob. $>\mathrm{F}=0.000$ which indicates that null hypothesis of autocorrelation is rejected and autocorrelation is detected in model. Results of Breusch-Pagan / Cook-Weisberg test for heteroskedasticity shows that Prob. > chi2 $=0.000$. Therefore, it again rejects the null hypothesis and heteroskedasticity is detected. To solve problem of heteroskedasticity and autocorrelation, Feasible Generalized Least Square method was applied.

As reported in Table 4, EVA, EVAMA and EVAM studied being Economic Value-Added measures showed a significant relationship with Stock Return reported the p-value of less than 0.01

\subsection{Conventional Accounting Measures and Stock Returns}

The third model of research was examined to check the individual effects of conventional accounting measures on stock returns. This impact was analyzed by regressing the accounting measures ROA, ROE, EPS and ROCE on the stock returns in the multiple linear regression model of the form:

$$
\mathbf{S R}_{\mathrm{it}}=\boldsymbol{\beta}_{\mathbf{0}}+\boldsymbol{\beta}_{1} * \mathrm{ROCE}_{\mathrm{it}}+\boldsymbol{\beta}_{2} * \mathrm{ROE}_{\mathrm{it}}+\boldsymbol{\beta}_{3} * \mathrm{EPS}_{\mathrm{it}}+\boldsymbol{\beta}_{\mathbf{4}} * \mathrm{ROA}_{\mathrm{it}}+\boldsymbol{\mu}_{\mathrm{it}}
$$

As shown in Table 3, the p-value of F-statistic is greater than 0.10 which means the model doesn't fit significantly on the data. The R-square of the model shows that only 23.6 percent of the variations in the stock return are due to conventional accounting measures. The other part of table shows that Return on Capital Employed has significant relationship with the stock return with pvalue less than 0.05 whereas ROE, EPS and ROA has shown the insignificant Effects on the Stock returns. This result is also consistent with the De Wet (2005). The results of Variance Inflating Factors concluded that there was no Multicollinearity found in the data as the mean VIF was less than 10. Results of Breusch-Pagan / Cook-Weisberg test for heteroskedasticity shows that Prob. > chi2 $=0.000$; hence the heteroskedasticity was detected in the data. Wooldridge test for autocorrelation in panel data shows that Prob. $>\mathrm{F}=0.000$ which indicates that the null hypothesis of autocorrelation is rejected and autocorrelation was detected in the model. As discussed by Kalsie and Shrivastav (2016), FGLS regression model was performed to deal with the problem of serial correlation and heteroskedasticity. The results of FGLS regression model pointed out in Table 4 shows that ROE, ROA, and EPS being the performance indicators does not have significant impact on the stock returns of the investors.

\section{Conclusion and Implications}

The research considered the sample of 107 listed companies with the highest market capitalization from 2011 to 2018. The scope of this research was limited to the Pakistan Stock Exchange, excluding the financial institutions. The factors, including the tax system, government policies, political instability, and market efficiency, are not considered in this research. The scope of this study also excluded the influence of speculation, short selling, and other behavioral biases on stock returns. 
The study deployed a deep methodology, including various statistical techniques, to ensure data reliability and recognize its characteristics. Based on sample data, the panel data regression techniques were used during the analysis to investigate whether the economic value-added measures influence the stock returns as compared to peer traditional accounting measures. The results provided that the FGLS regression pointed out towards a joint insignificant relationship between the EVA, EVAMA, EVAM, EVAS, ROA, ROE, EPS, ROCE and Stock Returns. In the second analysis, EVA, EVAMA, and EVAM studied being Economic Value-Added measures pointed out towards a significant relationship with Stock Return. Finally, in the third analysis, the FGLS regression model, as shown in Table 4, pointed out that ROE, ROA, and EPS being the performance indicators does not have significant effects on the stock returns of the investors. Hence, we conclude that in Pakistan, the conventional accounting measures doesn't influence the stock returns of the stock exchange, whereas the economic value-added measures reflect the fluctuation in stock prices of listed companies. In other words, if the company doesn't provide economic value to the shareholders, it can be ascertained that its share price might go down, as also discussed by (Fayed \& Dubey, 2016b).

Based on the above conclusion, it is recommended to apply the study over the Financial Sector of the economy. It is also suggested to consider other factors, including financial transparency, firm's tax-evading policies, and strong accountability, as considered by López-Arceiz et al. (2018). Due to the high political instability incurred in Pakistan, it is highly recommended to include the political influence on stock returns of listed companies, as considered by Liu et al. (2012) in China. The measurement of a firm's performance is also dependent on the types of investors, so it is recommended to consider whether the investors are foreign investors (Dong et al., 2019), individual or institutional investors.

\section{References}

Adamu, A., \& Haruna, J. (2020). Ownership structures and firm performance in Nigeria: A canonical correlation analysis. Journal of Research in Emerging Markets, 2(4), 21-32.

Ahmed, R., \& Bhuyan, R. (2020). Capital structure and firm performance in Australian service sector firms: A panel data analysis. Journal of Risk Financial Management, 13(9), 214.

Al-Awawdeh, H. A. (2018). The Impact of Economic Value Added, Market Value Added and Traditional Accounting Measures on Shareholders $i^{-}$Value: Evidence from Jordanian Commercial Banks. International Journal of Economics Finance, 10(10), 1-40.

Alsartawi, A. M. (2018). Online financial disclosure and firms' performance: Evidence from the Gulf Cooperation Council countries. World Journal of Entrepreneurship, Management Sustainable Development.

Amyulianthy, R., \& Ritonga, E. K. (2016). The Effect Of Economic Value Added And Earning Per Share To Stocks Return (Panel Data Approachment). International Journal of Business and Management Invention, 5(2), 8-15.

Angulo-Ruiz, F., Donthu, N., Prior, D., \& Rialp, J. (2018). How does marketing capability impact abnormal stock returns? The mediating role of growth. Journal of Business Research, 82, 19-30.

Anwaar, M. (2016). Impact of firms performance on stock returns (evidence from listed companies of ftse-100 index london, uk). Global Journal of Management and Business Research.

Aslam, M. I., \& Khan, A. A. (2015). Comparison of Traditional and Modern Performance Instruments on Selected Companies from Pakistan. International Review of Management and Marketing, 5(4), 242-245.

Awan, A. G., Siddique, K., \& Sarwar, G. (2014). The effect of economic value added on stock return: evidence from selected companies of Karachi stock exchange. Research Journal of Finance and Accounting, 5(23), 140-152.

Basit, A., \& Hassan, Z. (2017). Impact of capital structure on firms performance: a study on Karachi Stock Exchange (KSE) listed firms in Pakistan. International Journal of Management, Accounting and Economics(2017), 118-135. 
Baum, C. F. (2001). Residual diagnostics for cross-section time series regression models. The Stata Journal, 1(1), 101-104.

Baybordi, A., Nejad, K. G., \& Kargar, E. F. (2015). Evaluating the relationship between economic value-added and stock return in companies listed at tehran stock exchange. Management and Administrative Science Review, 4(1), 215-221.

Bhasin, M. L. (2017). A study of economic value added disclosures in the annual reports: Is EVA a superior measure of corporate performance. East Asian Journal of Business Economics, 5(1), 10-26.

Biddle, G. C., Bowen, R. M., \&, \& Wallace, J. S. (1997). Does EVA® beat earnings? Evidence on associations with stock returns and firm values. Journal of accounting economics, 24(3), 301-336. doi:http://dx.doi.org/10.2139/ssrn.2948

Biddle, G. C., Bowen, R. M., \& Wallace, J. S. (1998). Economic Value Added: Some Empirical Evidence. Managerial Finance, 24(11), 60-71.

Breusch, T. S., \& Pagan, A. R. (1979). A simple test for heteroscedasticity and random coefficient variation. Econometrica: Journal of the Econometric Society, 1287-1294.

Ciftci, I., Tatoglu, E., Wood, G., Demirbag, M., \& Zaim, S. (2019). Corporate governance and firm performance in emerging markets: Evidence from Turkey. International Business Review, 28(1), 90-103.

De Wet, J. (2005). Eva Versus Traditional Accounting Measures of Performance as Drivers of Shareholder Value - A Comparative Analysis. Meditari: Research Journal of the School of Accounting Sciences, 13(2), 1-16.

Dong, P., Thuy, T., \& Tra, N. (2019). Foreign investment, corporate governance and firm performance in Vietnam listed companies. Indian Journal of Economics Development, 15(4), 499-507.

Edet, B. N. (2015). Effect of market structure and conduct on the performance of selected agrobased firms in Nigeria. International Journal of Management Sciences Business Research.

Elamir, E. A. (2020). Boosting Algorithms to Analyse Firm's Performance Based on Return on Equity: An Explanatory Study. nternational Journal of Computing Digital Systems, 10, 117.

Fadte-Gaonkar, A., Parab, N., \& Reddy, Y. (2018). Exploring the causality between EVA and Stock Market Returns: Evidence from India.

Fayed, A. M., \& Dubey, S. (2016a). An empirical study of impact of EVA momentum on the shareholders value creation as compared to traditional financial performance measures-with special reference to the UAE. International Journal of Economics and Finance, 8(5), 23-38.

Fayed, A. M., \& Dubey, S. (2016b). An empirical study of impact of eva momentum on the shareholders value creation as compared to traditional financial performance measures-With special reference to the UAE. International Journal of Economics Finance, 8(5), 23-38.

Gounder, C. G., \& Venkateshwarlu, M. (2017). Shareholder Value Creation: An Empirical Analysis of Indian Banking Sector. Accounting and Finance Research, 6(1), 148-157.

Gupta, V. K., \& Sikarwar, E. (2016). Value creation of EVA and traditional accounting measures: Indian evidence. International Journal of Productivity Performance Management.

Har, W. P., \& Ghafar, M. A. A. (2015). The impact of accounting earnings on stock returns: the case of Malaysia's plantation industry. International Journal of Business and Management, 10(4), 155. doi:https://doi.org/10.5539/ijbm.v10n4p155

Hunjra, A. I., Ijaz, M., Chani, D., Irfan, M., \& Mustafa, U. (2014). Impact of dividend policy, earning per share, return on equity, profit after tax on stock prices. Hunjra, AI, Ijaz, M. S, Chani, MI, Hassan, S. and Mustafa, U.(2014). Impact of Dividend Policy, Earning per Share, Return on Equity, Profit after Tax on Stock Prices. International Journal of Economics and Empirical Research, 2(3), 109-115.

Iqbal, U., Gan, C., \& Nadeem, M. (2020). Economic policy uncertainty and firm performance. Applied Economics Letters, 27(10), 765-770. 
Ismail, M., Aslam, M. I., \& Zubair, M. (2014). Effect of traditional and modern performance instruments on selected companies from Pakistan. Science International (Lahore), 26(5), 2617-2619.

Johan, S. (2018). The Relationship Between Economic Value Added, Market Value Added And Return On Cost Of Capital In Measuring Corporate Performance. Jurnal Manajemen Bisnis dan Kewirausahaan, 2(1).

Kalsie, A., \& Shrivastav, S. M. (2016). Analysis of board size and firm performance: evidence from NSE companies using panel data approach. Indian Journal of Corporate Governance, 9(2), 148-172.

Khadafi, M., Heikal, M., \& Ummah, A. (2014). Influence analysis of return on assets (ROA), return on equity (ROE), net profit margin (NPM), debt to equity ratio (DER), and current ratio (CR), against corporate profit growth in automotive in Indonesia Stock Exchange. International Journal of Academic Research in Business and Social Sciences, 4(12). doi:10.6007/IJARBSS/v4-i12/1331

Khan, S., Chouhan, V., Chandra, B., \& Goswami, S. (2012). Measurement of Value Creation VisÀ-Vis EVA: Analysis of Select BSE Companies. Pacific Business Review International, 5(3), 114-131.

Khanam, F., Nasreen, S., \& Pirzada, S. S. (2014). Impact of capital structure on firm's financial performance: Evidence from food sector of Pakistan. Research Journal of Finance Accounting, 5(11), 93-105.

Khani, A., Botshekan, M., \& Athari, B. (2020). The Evaluation of the Managed Momentum Strategy in the Listed Companies on Tehran Stock Exchange. Financial Management Strategy, 8(4), 23-50.

Kumar, K., \& Subramanyam, D. (2017). Shareholders' Value Analysis: EVA \& MVA in Relation to Stock Market Returns with Reference to the Indian Cement Industry.

Kumar Rai, S., \& Shaikh, I. (2020). Does the performance of private investment in public equity firms behave differently in different life cycles? Applied Economics, 1-17.

Lehn, K., \& Makhija, A. K. (1997). EVA, accounting profits, and CEO turnover: an empirical examination, 1985-1994. Journal of applied corporate finance, 10(2), 90-97.

Levin, A., Lin, C.-F., \& Chu, C.-S. J. J. J. o. e. (2002). Unit root tests in panel data: asymptotic and finite-sample properties. 108(1), 1-24.

Liu, J., Uchida, K., \& Gao, R. (2012). Political connections and the long-term stock performance of Chinese IPOs. Journal of International Financial Markets, Institutions Money, 22(4), 814833.

López-Arceiz, F. J., Bellostas-Pérezgrueso, A. J., Moneva-Abadía, J. M., \& Rivera-Torres, M. P. (2018). The role of corporate governance and transparency in the generation of financial performance in socially responsible companies. Spanish Journal of Finance Accounting/Revista Española de Financiación y Contabilidad, 47(1), 44-80.

Maditinos, D. I., Šević, Ž., \& Theriou, N. G. (2009). Modelling traditional accounting and modern value-based performance measures to explain stock market returns in the Athens Stock Exchange (ASE). Journal of Modelling in Management.

Maeenuddina, R. B., Hussain, A., Hafeez, M., Khan, M., \& Wahi, N. (2020a). Economic Value Added Momentum \& Traditional Profitability Measures (ROA, ROE \& ROCE): A Comparative Study. TEST-Engineering Management, 83, 13762-13774.

Maeenuddina, R. B., Hussain, A., Hafeez, M., Khan, M., \& Wahi, N. (2020b). Economic Value Added Momentum \& Traditional Profitability Measures (ROA, ROE \& ROCE): A Comparative Study. TEST-Engineering Management, 83, 13762-13774.

Mahmood, W., Mansor, W., \& Norfarah Hani, Y. (2008). Creating Wealth for Shareholders: Evaluating the Performance of the Malaysia Property Companies.

Maitah, M., Saleem, N., Malec, K., Boubaker, M., \& Gouda, S. (2015). Economic value added and stock market development in Egypt. Asian Social Science, 11(3), 126. 
Mengi, T., \& Bhatia, B. S. (2017). Shareholder value creation--comparison of traditional accounting measures and EVA as predictors of MVA (09702385). Retrieved from https://go.gale.com/ps/anonymous?id=GALE\%7CA507357609\&sid=googleScholar\&v=2.1 \&it=r\&linkaccess $=a b s \& i s s n=09702385 \& p=A O N E \& s w=w$

Menike, M., \& Prabath, U. (2014). The Impact of Accounting Variables on Stock Price: Evidence from the Colombo Stock Exchange, Sri Lanka. International Journal of Business and Management, 9(5), 125. doi:https://doi.org/10.5539/ijbm.v9n5p125

Mughal, Y. H., Jehangir, M., Khan, M., \& Saeed, M. (2020). Nexus between corporate social responsibility and firm's performance: A panel data approach. International Journal of Finance Economics.

Muhammad, N., \& Scrimgeour, F. (2014). Stock returns and fundamentals in the Australian market. Asian Journal of Finance \& Accounting, 6(1), 271-290. doi:10.5296/ajfa.v6i1.5486

Nakhaei, H., \& Hamid, N. (2013). Analyzing the relationship between economic value added (EVA) and accounting variables with share market value in Tehran stock exchange (TSE). Middle-East Journal of Scientific Research, 16(11), 1589-1598. doi:10.5829/idosi.mejsr.2013.16.11.12053

NGUYEN, H. T., \& NGUYEN, A. H. (2020). The impact of capital structure on firm performance: Evidence from Vietnam. The Journal of Asian Finance, Economics,Business, 7(4), 97-105.

O'Byrne, S. (2019). Using EVA to Measure Management's Contribution to Value-A Missed Opportunity at ISS. Available at SSRN 3500538.

O'Byrne, S. F. (1996). EVA® and Market value. Journal of applied corporate finance, 9(1), 116126. doi:https://doi.org/10.1111/j.1745-6622.1996.tb00109.x

O'Byrne, S. F. (2019). Using EVA to Measure Management's Contribution to Value-A Missed Opportunity at ISS. Available at SSRN 3500538.

Panigrahi, S., Zainuddin, Y., \& Azizan, N. (2014). Linkage of management decisions to shareholder's value: EVA concept. International Journal of Finance Banking Studies, 3(1).

Panigrahi, S. A. (2017). Economic Value Added and traditional accounting measures for shareholder's wealth creation. Asian Journal of Accounting Governance, 8, 125-136.

Panigrahi, S. K. (2017). Economic Value Added and Traditional Accounting Measures for Shareholder's Wealth Creation. Asian Journal of Accounting and Governance, 8, 125-136.

Parab, N., \& Reddy, Y. (2018). Impact of financial performance indicators on stock returns: Evidence from India.

Patel, R., \& Patel, M. (2012). Impact of Economic value added (EVA) on Share price: A study of Indian Private Sector banks. International Journal of Contemporary Business Studies, 3(1).

Peixoto, S. M. (2002). Economic value added (R)-application to Portuguese public companies. Available at SSRN 302687. doi:http://dx.doi.org/10.2139/ssrn.302687

Saleh, M. (2015). Relationship between Firm's Financial Performance and Stock Returns: Evidence from Oil and Gas Sector Pakistan. Journal of Energy Technologies and Policy, ISSN, 22243232.

Sauro, M., \& Tafirei, M. (2016). EVA and Stock Returns: Are They Correlated? Financial Assets and Investing, 7(2), 34-51.

Sekyere, G. O. (2016). Empirical Forecasting of Returns during the Great Recession through Economic Value Added.

Shehzad, K., \& Ismail, A. (2014). Value relevance of accounting information and its impact on stock prices: Case study of listed banks at Karachi Stock Exchange. Journal of Economic Info, 1(3), 6-9.

Shubita, M. F. (2013). The Information Content of Economic Value Added and Residual Income Evidence from Jordan. Journal of Economics and Sustainable Development, 4(13), 124-131.

Smith, M. P. (1996). Shareholder activism by institutional investors: Evidence from CalPERS. The journal of finance, 51(1), 227-252.

Stewart, B. (2009). EVA momentum: the one ratio that tells the whole story. Journal of applied corporate finance, 21(2), 74-86. doi: https://doi.org/10.1111/j.1745-6622.2009.00228.x 
Stewart, B. (2019). EVA, not EBITDA: A New Financial Paradigm for Private Equity Firms. Journal of applied corporate finance, 31(3), 103-115.

Stewart, G. B. (1990). The Quest for value: The EVA TM management guide.

Subedi, M., \& Farazmand, A. (2020). Economic Value Added (EVA) for Performance Evaluation of Public Organizations. Public Organization Review, 20(4), 613-630.

Taebi Noghondari, A., \& Abbaszadeh, M. (2017). Moderating effect of firm size on relationship between corporate governance and corporate economic performance. Journal of Accounting of Knowledge, 8(1), 155-182.

Tirumalsety, R., \& Gurtoo, A. (2021). Financial sources, capital structure and performance of social enterprises: empirical evidence from India. Journal of Sustainable Finance Investment, $11(1), 27-46$.

Tripathi, M., Kashiramka, S., \& Jain, P. (2018). Flexibility in measuring corporate financial performance, EVA versus conventional earnings measures: Evidences from India and China. Global Journal of Flexible Systems Management, 19(2), 123-138.

Visaltanachoti, N., Luo, R., \& Yi, Y. (2008). ECONOMIC VALUE ADDED (EVA) AND SECTOR RETURNS. Asian Academy of Management Journal of Accounting \& Finance, 4(2).

Wirawan, D. I. (2011). Effects of EVA (Economic Value Added), EVA Spread, EVA Momentum and Return on Assets ON Stock Return (THESIS, Empirical Study in Indonesian Stock Market). Gadjah Mada University, Indonesia,

Wooldridge, J. M. (2010). Econometric analysis of cross section and panel data: MIT press.

Worthington, A. C., \& West, T. (2004). Australian Evidence Concerning the Information Content of Economic Value-Added. Australian Journal of Management, 29(2), 201-223. 
Table 1 : Sector wise distribution of sample

$\begin{array}{llll}\text { Sr. no } & \text { Sectors } & \text { No of firms } & \text { \% } \\ \mathbf{1} & \text { Cement } & 9 & 8 \\ \mathbf{2} & \text { FOOD \& PERSONAL CARE PRODUCTS } & 3 & 3 \\ \mathbf{3} & \text { ENGINEERING } & 5 & 5 \\ \mathbf{4} & \text { CHEMICAL } & 17 & 16 \\ \mathbf{5} & \text { POWER } & 3 & 3 \\ \mathbf{6} & \text { Sugar } & 16 & 15 \\ \mathbf{7} & \text { AUTOMOBILE Parts } & 14 & 13 \\ \mathbf{8} & \text { Fertilizers } & 4 & 4 \\ \mathbf{9} & \text { OIL \& GAS } & 10 & 9 \\ \mathbf{1 0} & \text { TEXTILE COMPOSITE } & 12 & 11 \\ \mathbf{1 1} & \text { PHARMACEUTICALS } & 6 & 6 \\ \mathbf{1 2} & \text { SYNTHETIC \& RAYON } & 4 & 4 \\ \mathbf{1 3} & \text { Glass \& Ceramics } & 4 & 4\end{array}$


Table 2: Operationalization of Variables

\begin{tabular}{|c|c|c|}
\hline Variables & Formulae/Measurements & Sources \\
\hline Return on Equity & $\begin{array}{l}\text { (Net Profit After Tax/Average Total } \\
\text { Equity) } * 100\end{array}$ & $\begin{array}{l}\text { Iqbal et al. (2020); Elamir (2020); } \\
\text { Kumar Rai and Shaikh (2020) }\end{array}$ \\
\hline Return on Assets & $\begin{array}{l}\text { (Net Profit After Tax/Average Total } \\
\text { Assets) } * 100\end{array}$ & $\begin{array}{l}\text { Ahmed and Bhuyan } \\
\text { Adamu and Haruna } \\
\text { NGUYEN and NGUYEN (2020); } \\
\text { NGU) }\end{array}$ \\
\hline $\begin{array}{lll}\text { Return on } & \text { Capital } \\
\text { Employed } & & \\
\end{array}$ & $\begin{array}{l}\text { (Operating Profit/ Capital Invested) } \\
* 100\end{array}$ & $\begin{array}{l}\text { Tirumalsety and Gurtoo (2021); } \\
\text { Khanam et al. (2014); Edet (2015) }\end{array}$ \\
\hline Earnings Per Share & $\begin{array}{l}\text { Net Profit After Tax/ No of shares } \\
\text { outstanding. }\end{array}$ & $\begin{array}{l}\text { Basit and Hassan (2017); } \\
\text { (Alsartawi, 2018); Mughal et al. } \\
\text { (2020) }\end{array}$ \\
\hline Economic Value Added & $\begin{array}{l}\text { Net Operating Profit After Tax } \\
\text { (NOPAT) - (Capital Invested * } \\
\text { WACC) }\end{array}$ & $\begin{array}{l}\text { Bennett Stewart (2019); Subedi } \\
\text { and Farazmand (2020); Tripathi et } \\
\text { al. (2018) }\end{array}$ \\
\hline $\begin{array}{l}\text { Economic } \text { Value-Added } \\
\text { Margin }\end{array}$ & $\begin{array}{l}\text { (Economic Value Added / Sales) * } \\
100\end{array}$ & Bhasin (2017); S. O'Byrne (2019) \\
\hline $\begin{array}{l}\text { Economic } \quad \text { Value-Added } \\
\text { Momentum }\end{array}$ & $\begin{array}{l}\text { ((Current Year Economic Value } \\
\text { Added - Previous Year Economic } \\
\text { Value Added)/Sales) } * 100\end{array}$ & $\begin{array}{l}\text { Khani et al. (2020); Maeenuddina } \\
\text { et al. (2020b); Taebi Noghondari } \\
\text { and Abbaszadeh (2017) }\end{array}$ \\
\hline $\begin{array}{ll}\text { Economic } & \text { value-Added } \\
\text { Spread } & \\
\end{array}$ & $\begin{array}{l}\text { (Economic Value Added / Capital } \\
\text { Invested) } * 100\end{array}$ & S. F. O'Byrne (2019) \\
\hline Stock Return & $\begin{array}{l}\text { ((Current year Price }- \text { previous year } \\
\text { Price }+ \text { Dividend }) / \text { Previous Year } \\
\text { Price }) * 100\end{array}$ & $\begin{array}{l}\text { Angulo-Ruiz et al. (2018); Fadte- } \\
\text { Gaonkar et al. (2018); Kumar and } \\
\text { Subramanyam (2017) }\end{array}$ \\
\hline
\end{tabular}


Table 3: Results of Panel OLS Regression Model, Autocorrelation, and Heteroskedasticity

\begin{tabular}{|c|c|c|c|c|c|c|c|}
\hline \multicolumn{6}{|c|}{ Dependent variable: Stock Returns } & $\begin{array}{l}\text { Wooldridg } \\
\text { e test for } \\
\text { Autocorrel } \\
\text { ation in } \\
\text { panel data }\end{array}$ & $\begin{array}{l}\text { Breusch-Pagan } \\
\text { / Cook- } \\
\text { Weisberg test } \\
\text { for } \\
\text { heteroskedastic } \\
\text { ity }\end{array}$ \\
\hline & \multirow[b]{2}{*}{$\begin{array}{l}\text { Independent } \\
\text { variables }\end{array}$} & \multicolumn{4}{|c|}{ Panel OLS Regression Analysis } & \multirow[b]{2}{*}{$F(1,34)$} & \multirow[b]{2}{*}{ CHI2(1) } \\
\hline & & Coeff. & VIF & $\begin{array}{l}\text { F } \\
\text { statisti } \\
\text { cs }\end{array}$ & $\begin{array}{l}\text { R-Sq. } \\
\text { (Sig.) }\end{array}$ & & \\
\hline \multirow{8}{*}{$\frac{\overline{0}}{\overline{0}}$} & EVA & $9.88 \mathrm{e}-09 * * *$ & 1.65 & \multirow{8}{*}{15.04} & \multirow{8}{*}{0.31} & \multirow{8}{*}{$22.274 * * *$} & \multirow{8}{*}{$4689.93 * * *$} \\
\hline & EVAMA & $-848.76 * * *$ & 4.36 & & & & \\
\hline & EVAS & 1.75 & 2.91 & & & & \\
\hline & EVAM & $2.38 * * * *$ & 2.64 & & & & \\
\hline & ROA & -5.74 & 2.59 & & & & \\
\hline & ROE & -0.57 & 1.99 & & & & \\
\hline & ROCE & 1.18 & 1.54 & & & & \\
\hline & EPS & -0.68 & 1.5 & & & & \\
\hline \multirow{4}{*}{ 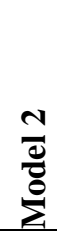 } & EVAMA & $-834.03 * * *$ & 4.11 & \multirow{4}{*}{27.71} & \multirow{4}{*}{0.29} & \multirow{4}{*}{$23.172 * * *$} & \multirow{4}{*}{$4523.09 * * *$} \\
\hline & EVAM & $2.70 * * *$ & 2.54 & & & & \\
\hline & EVAS & $.83 * * *$ & 2.32 & & & & \\
\hline & EVA & $9.65 \mathrm{E}-09$ & 1.6 & & & & \\
\hline \multirow{4}{*}{$\frac{m}{\frac{\pi}{0}}$} & ROA & -3.85 & 2.19 & \multirow{4}{*}{1.17} & \multirow{4}{*}{0.02} & \multirow{4}{*}{8.95} & \multirow{4}{*}{$757.92 * * *$} \\
\hline & ROE & -0.041 & 1.98 & & & & \\
\hline & ROCE & $2.15^{* *}$ & 1.51 & & & & \\
\hline & EPS & -0.58 & 1.33 & & & & \\
\hline
\end{tabular}

Note: $* * * \mathrm{p} \leq 0.01 ; * * \mathrm{p} \leq 0.05 ; * \mathrm{p} \leq 0.10$

Source: Calculations based on Author's Panel Data 
Table 4: Results of feasible general least squares (FGLS)

\begin{tabular}{|c|c|c|c|}
\hline \multicolumn{4}{|c|}{ CROSS-SECTIONAL TIME-SERIES FGLS REGRESSION } \\
\hline \multicolumn{4}{|c|}{ COEFFICIENTS: GENERALIZED LEAST SQUARES } \\
\hline \multicolumn{4}{|c|}{ PANELS: $\quad$ HOMOSKEDASTIC } \\
\hline \multicolumn{4}{|c|}{ CORRELATION: NO AUTOCORRELATION } \\
\hline \multirow{9}{*}{$\begin{array}{l}\bar{\theta} \\
\frac{\bar{g}}{8} \\
\sum\end{array}$} & Independent Variables & Coeff. & Wald chi-Sq. (Sig.) \\
\hline & EVA & $9.88 \mathrm{e}-09 * * *$ & \multirow{8}{*}{$124.34 * * *$} \\
\hline & EVAMA & $-848.76^{* * *}$ & \\
\hline & EVAM & $2.38 * * *$ & \\
\hline & EVAS & $1.75^{*}$ & \\
\hline & ROCE & 1.18 & \\
\hline & $\mathrm{ROE}$ & -0.57 & \\
\hline & EPS & -0.68 & \\
\hline & ROA & $-5.74 *$ & \\
\hline \multirow{4}{*}{$\frac{N}{\frac{N}{8}}$} & EVA & $9.65 \mathrm{e}-09 * * *$ & \multirow{4}{*}{$112.87 * * *$} \\
\hline & EVAMA & $-834.03 * * *$ & \\
\hline & EVAM & $2.70 * * *$ & \\
\hline & EVAS & 0.83 & \\
\hline \multirow{4}{*}{$\frac{m}{\stackrel{0}{0}}$} & ROCE & $2.15 * *$ & \multirow{4}{*}{$4.78(0.31)$} \\
\hline & $\mathrm{ROE}$ & -0.041 & \\
\hline & EPS & -0.58 & \\
\hline & ROA & -3.85 & \\
\hline
\end{tabular}

Note: ${ }^{* *} \mathrm{p} \leq 0.01 ; * * \mathrm{p} \leq 0.05 ;{ }^{*} \mathrm{p} \leq 0.10$

Source: Calculations based on Author's Panel Data 